\title{
Improved Salt Quality and Reduced Energy Consumption via Hot Air Drying
}

\author{
Nizar Amir ${ }^{1,3}$, Makhfud Efendy²,3, Young Je Yoo ${ }^{4}$, Misri Gozan ${ }^{*}$ \\ ${ }^{1}$ Department of Mechanical Engineering, University of Trunojoyo Madura, Telang, Kamal, Bangkalan, East \\ Java, 69162, Indonesia \\ ${ }^{2}$ Department of Marine Science, University of Trunojoyo Madura, Telang, Kamal, Bangkalan, East Java, 69162, \\ Indonesia \\ ${ }^{3}$ Salt Centre of Excellence, University of Trunojoyo Madura, Telang, Kamal, Bangkalan, East Java, 69162 \\ Indonesia \\ ${ }^{4}$ School of Chemical \& Biological Engineering, Seoul National University, 599 Gwanak-ro, Gwanak-gu, Seoul \\ 151-744, Korea \\ ${ }^{5}$ Chemical Engineering Department, Universitas Indonesia, Kampus UI Depok, Depok 16424, Indonesia
}

\begin{abstract}
This study examines the effects of hot air drying operating parameters on salt quality and energy consumption. Temperature, air velocity, and drying time were modified to evaluate their effects on $\mathrm{NaCl}$ percentage, water content, whiteness, and hot air drying energy consumption. The results showed that increasing temperatures, air velocities, and drying times decreased water content and increased salt temperatures. Additionally, given several operating parameters, $\mathrm{NaCl}$ percentage and whiteness initially increased to an optimum value and decreased, respectively. The decrease in $\mathrm{NaCl}$ percentage and whiteness is due to salt's rapid decomposition with hightemperature heating to form a yellow residue. Increasing temperatures and drying times increased energy consumption and decreased drying energy efficiency. However, increasing air velocities increased both energy consumption and drying energy efficiency. The most economical values for energy consumption and drying energy efficiency for one operation cycle were $1.79 \mathrm{kWh}$ and $17 \%$, respectively. This study found that the lowest energy consumption and highest energy efficiency while maintaining high salt quality were achieved at $70^{\circ} \mathrm{C}$ with an air velocity of $22.5 \mathrm{~m} / \mathrm{s}$ and a drying time of $30 \mathrm{~min}$.
\end{abstract}

Keywords: Hot air drying; Hot air performance; Salt; Salt drying; Sodium chloride quality

\section{Introduction}

Salt is an essential material worldwide, used in many modern industrial applications (Khormali et al., 2016; Aslfattahi et al., 2019; Sofyan et al., 2019), as well as human consumption (Rochwulaningsih et al., 2019a; Rochwulaningsih et al., 2019b). Indonesia's demand for salt has continually grown at a tremendous rate over the last few decades (Juwono, 2020). The country's growing chemical industry and population have accelerated this growth. Consequently, demand has increased for high-quality salt with low production costs. High-quality salt requires that salt be dried to a feasible water content after processing (Zhao et al., 2008). The drying process comprises two phases: heating and drying. It occurs through changes to temperature, relative humidity, and airflow (Palamba

*Corresponding author's email: mrgozan@gmail.com, Tel.: +62-021-7863516; Fax.: +62-021-7863515 doi: 10.14716/ijtech.v12i3.4853 
et al., 2018). The drying process removes water from solid salt particles via evaporation. Drying helps store salt for lengthy periods and improves its quality. The challenge in drying salt is reducing the water content without sacrificing quality since natural elemental impurities - such as sulfate $\left(\mathrm{SO}_{4}{ }^{-2}\right)$, calcium (Ca), and magnesium (Mg) - may adversely affect public health (Heydarieh et al., 2020). Moreover, salt drying consumes energy, so its operating parameters must be chosen correctly. For example, a high temperature during salt drying should be avoided because it turns salt yellow (McGee and Diosady, 2016). A variety of strategies are required to obtain the maximum use of positive energy flow production (Harahap et al., 2020). Various drying systems have been applied to salt drying, such as rotary dryers (Jafari and Farahbod, 2017), fluidized bed dryers (Zhao et al., 2008), and hot air dryers (Qadir et al., 2005). Hot air drying has attracted much attention because it offers a wide range of applications, such as drying herbs (Liang et al., 2020), agricultural products (Das and Arora, 2018; Deepika and Sutar, 2018; Gao et al., 2019), and wood products (Khamtree et al., 2019). Operating parameters - such as temperature, air velocity, and drying time-influence product quality when drying with hot air (Zhu, 2018). The current study aimed to investigate the effect of hot air drying parameters - such as temperature, air velocity, and drying time-on salt quality in terms of $\mathrm{NaCl}$ percentage, whiteness, and water content. The energy consumption and energy efficiency of hot air drying were also investigated.

\section{Materials and Methods}

\subsection{Salt}

Crude solar sea salt with an initial water content of around $11.5 \%$ on a wet basis (wb) was used in this study. The salt was obtained from a solar pond in Tajungan Village, Bangkalan Regency, East Java Province, Indonesia. The salt was randomly collected and transported to the experimental site in an aluminum foil pack to minimize environmental effects, such as air humidity and dust, which could have added more impurities to the salt. The undried salt's characteristics are listed in Table 1.

Table 1 Undried salt's characteristics

\begin{tabular}{lcc}
\hline \multicolumn{1}{c}{ Salt characteristics } & Unit & Information \\
\hline Source & - & Crude solar sea salt \\
Actual density & $\mathrm{kg} / \mathrm{m}^{3}$ & 2,176 \\
Particle size & $\mathrm{mm}$ & $5-100 \mathrm{~mm}$ \\
Initial NaCl & $\%$ & $90.7 \% \pm 0.5$ \\
Initial whiteness & - & $72.5 \pm 0.15$ \\
Initial water content $(\mathrm{wb})$ & $\%$ & $11.5 \%$ \\
\hline
\end{tabular}

\subsection{Drying Equipment}

Hot air heating equipment developed at the salt laboratory at the University of Trunojoyo Madura was used to conduct this study's experiments. A schematic diagram of this hot air heating equipment is presented in Figure 1. The hot air heating equipment was able to control the desired drying conditions over a wide range of operating parameters. Its dimensions were $600 \times 400 \times 200 \mathrm{~mm}$, and it had a $50-\mathrm{mm}$ thick wire mesh bed and a capacity for $5 \mathrm{~kg}$ of crude solar sea salt. The airflow was supplied by a centrifugal blower, which was powered by a 130 -watt electric motor. The heater element had a 5 -kW capacity 
and could reach $300^{\circ} \mathrm{C}$. The hot air heating motor operated with three phases, AC of 380 volts, and $60 \mathrm{~Hz}$. Air velocity and temperature sensor instrumentation measured the airflow before it entered the dryer box.

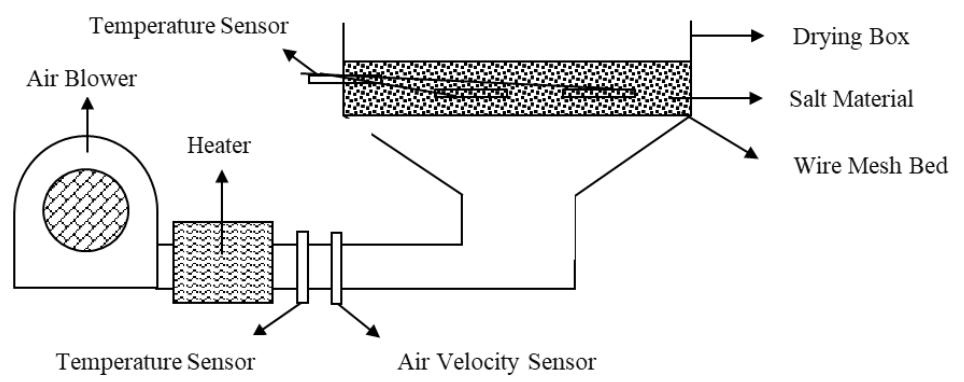

Figure 1 Schematic diagram of the hot air heating equipment

\subsection{Experimentation}

The crude solar sea salt used as a batch material had a loading weight of $5 \mathrm{~kg}$ and an initial water content of $11.5 \% \mathrm{wb}$. The study's experiments were conducted at different drying temperatures $\left(50^{\circ} \mathrm{C}, 60^{\circ} \mathrm{C}, 70^{\circ} \mathrm{C}, 80^{\circ} \mathrm{C}\right.$, and $\left.90^{\circ} \mathrm{C}\right)$, air velocities $(17.7,20,22.5,24.4$, and $27.5 \mathrm{~m} / \mathrm{s})$, and drying times $(30,45,60,75$, and $90 \mathrm{~min}$.). A flow control instrument regulated the air velocity in the air blower equipment while thermostats in the heater equipment controlled the temperature. The crude solar sea salt was carefully weighed with an electronic digital scale before it was fed into the drying box. The blower and heater were turned on, and once the desired temperature and air velocity were reached, the crude solar sea salt was fed into the drying box. The experiments were conducted by varying the temperature, air velocity, and drying time parameters. During the investigations, one parameter was varied at a time while the other parameters were maintained at a constant value. Every 10 min., the material was mixed with a stainless-steel fork to maintain equal heating. After the drying experiments had been completed, the crude solar sea salt was carefully removed from the drying box and wrapped in aluminum foil to avoid any environmental effects and then packed and sealed into polypropylene bags.

\subsection{Water Content}

Water content was calculated by measuring losses in mass, determined by drying at $105^{\circ} \mathrm{C}$ for six hours according to Equation 1:

$$
\text { Water content }(\% w b)=\frac{\text { Initial mass }(g) \text {-Final mass }(g)}{\text { Initial Mass }(g)} \times 100 \%
$$

This method followed ISO 2483:1973, a standard for determining mass losses in sodium chloride for industrial use. This international standard specifies a method for determining mass losses at $110^{\circ} \mathrm{C}$ (conventional moisture) in sodium chloride for industrial use.

\subsection{Sodium Chloride Content and Whiteness}

The crude solar sea salt's $\mathrm{NaCl}$ percentage and whiteness were measured using commercial equipment (Saltdec M102, Matra, Indonesia). This instrument was calibrated with a multifunction calibrator (ADT221A, Additel, USA) with an accuracy of $99.5 \% \pm 0.4$.

\subsection{Energy Consumption and Drying Energy Efficiency}

The drying equipment and blower consumed energy. The electric current was calculated from the power consumed by both the heating equipment and the blower in amps (A), as indicated by a digital electric measuring instrument. The drying equipment's energy consumption was calculated according to Equation 2: 


$$
E_{\text {electrical }}=\boldsymbol{V} \boldsymbol{x} \boldsymbol{A} \boldsymbol{x} \boldsymbol{t}_{\text {dry }}
$$

where $V$ is the electrical voltage (volt), $A$ is the electrical current (ampere), and $t_{d r y}$ is the drying time (hr). The amount of heat energy used to remove the water content from the product, divided by the amount of energy consumed by the hot air heating equipment, was calculated as the drying energy efficiency. Drying energy efficiency is an excellent way to measure the quality of a drying process. Equation 3 was used to determine drying energy efficiency:

$$
\boldsymbol{\eta}=\frac{\boldsymbol{m}_{\text {ew }} \gamma_{\text {ew }}}{\boldsymbol{E}_{\text {electrical }}}
$$

where $\eta$ is the drying energy efficiency, $m_{e w}$ is the mass of removed water $(\mathrm{kg})$, and $\gamma_{e w}$ is the latent heat of the water's vaporization $(\mathrm{kJ} / \mathrm{kg})$.

\section{Results and Discussion}

\subsection{Effect of Drying Temperature}

Drying temperatures' effect on drying crude solar sea salt was determined at $50^{\circ} \mathrm{C}$, $60^{\circ} \mathrm{C}, 70^{\circ} \mathrm{C}, 80^{\circ} \mathrm{C}$, and $90^{\circ} \mathrm{C}$, as shown in Figure 2 and Figure 3. During the experiment, the air blower velocity and drying time were kept constant at $27 \mathrm{~m} / \mathrm{s}$ and $30 \mathrm{~min}$., respectively. As Figure 2 shows, the hot air drying equipment rapidly removed the water content with increasing drying temperatures. The increase in drying temperatures significantly correlated with a rise in salt temperatures.

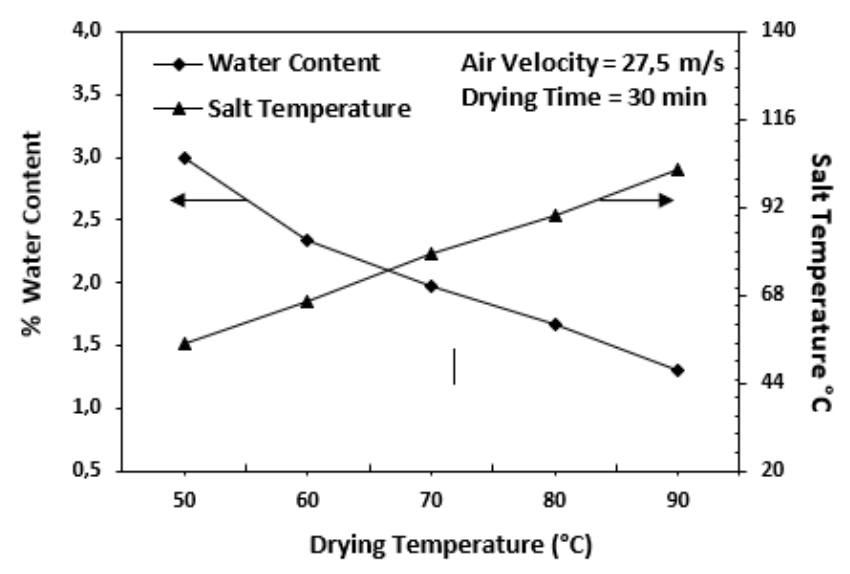

Figure 2 Drying temperatures' effect on salt's water content and temperature

An increase in drying temperature was shown to lead to increased heat supplied to the salt particles, causing rapid water removal. Salt particles have a high heat capacity, which increases their temperature. Drying temperatures' effect on $\mathrm{NaCl}$ percentages and whiteness was plotted and shown in Figure 3. When drying temperatures increased, the $\mathrm{NaCl}$ percentage and whiteness increased to optimum levels at $80^{\circ} \mathrm{C}$ and $70^{\circ} \mathrm{C}$, respectively. The salt particles' whiteness increased as their surface water content decreased. This whiteness then decreased when the drying temperatures were further increased to $90^{\circ} \mathrm{C}$ because an increasing $\mathrm{NaCl}$ percentage compensated for the water's removal. However, salt easily decomposes with high-temperature heating and forms a yellow residue, which decreases its $\mathrm{NaCl}$ percentage and whiteness, as Figure 3 shows.

Heating an alkali halide crystal is known to cause a colored center in the presence of metal or halogen vapor due to a defect in the crystal's lattice (Sonnenfeld, 1995; Li et al., 2010; Kuganathan and Chroneos, 2018; Perera et al., 2019;). 


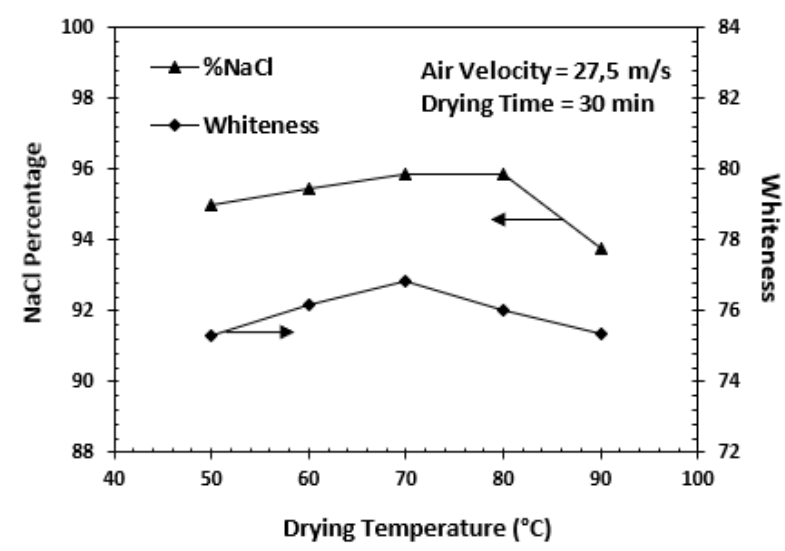

Figure 3 Drying temperatures' effect on $\mathrm{NaCl}$ percentage and whiteness

In this work, $\mathrm{NaCl}$ crystals were heated in the presence of the metal $\mathrm{Na}$. The $\mathrm{NaCl}$ crystals were heated with this $\mathrm{Na}$ metal vapor, causing adsorption of $\mathrm{Na}$ atoms at the crystals' surface. Sonnenfeld (1995) has long since demonstrated this yellow color in $\mathrm{NaCl}$ rock salt.

\subsection{Effect of Air Velocity}

Air velocities' effect on drying crude solar sea salt was tested at various air velocities $(17.7,20,22.5,24.4$, and $27.5 \mathrm{~m} / \mathrm{s})$, as Figure 4 and Figure 5 show. The drying temperature and drying time were fixed at $70^{\circ} \mathrm{C}$ and 30 min., respectively.

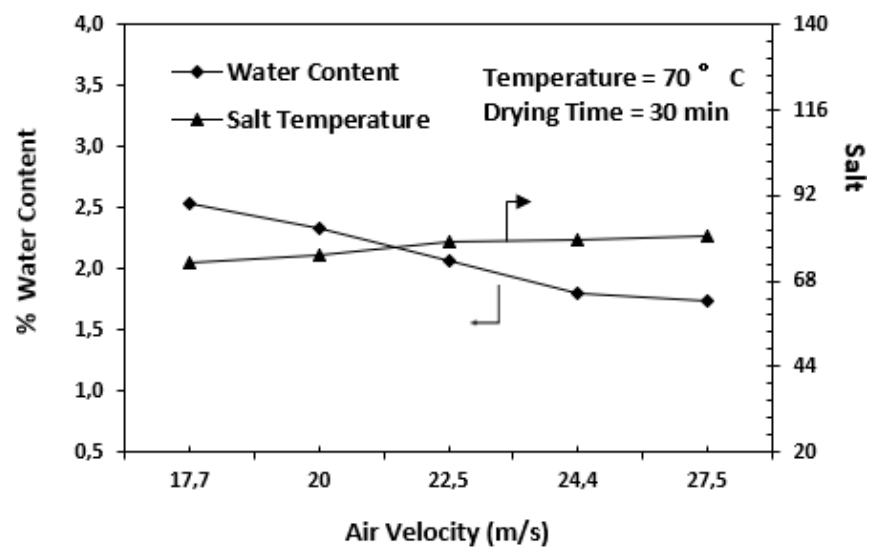

Figure 4 Air velocities' effect on salt's water content and temperature

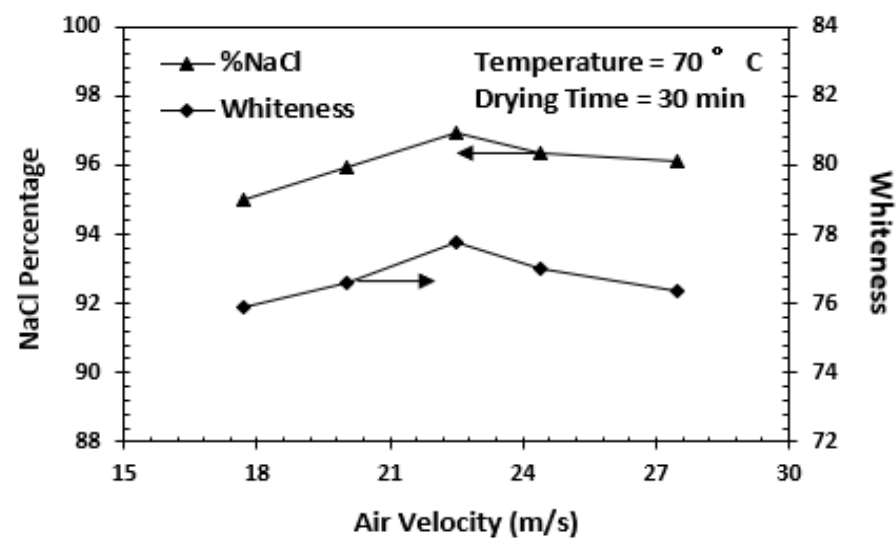

Figure 5 Air velocities' effect on $\mathrm{NaCl}$ percentage and whiteness 
The water content reduced from $2.53 \%$ to $1.73 \%$ when the air velocity was increased from 17.7 to $27.5 \mathrm{~m} / \mathrm{s}$. Increasing air velocities carried more heat via the airflow, leading to a higher heat transfer from the salt particles and water removal. Furthermore, increasing the air velocity increased the salt particles' temperature from $73.2^{\circ} \mathrm{C}$ to $80.4^{\circ} \mathrm{C}$. The salt's $\mathrm{NaCl}$ percentage initially increased to $96.91 \%$ as the air velocity increased to $22.5 \mathrm{~m} / \mathrm{s}$. Then, it decreased to $96.1 \%$ as the air velocity increased up to $27.5 \mathrm{~m} / \mathrm{s}$, as Figure 5 shows. Salt particles' crystal structure suffers excess flaws at higher temperatures, resulting in a yellow color and leading to decreased $\mathrm{NaCl}$ percentage and whiteness. The air velocity was determined to be the critical parameter; therefore, it should be appropriately selected to maximize drying performance and enhance salt particles' quality.

\subsection{Effect of Drying Time}

The drying times' effect on the salt particles' quality was investigated at $30,45,60$, 75, and 90 min., as Figure 6 and Figure 7 show.

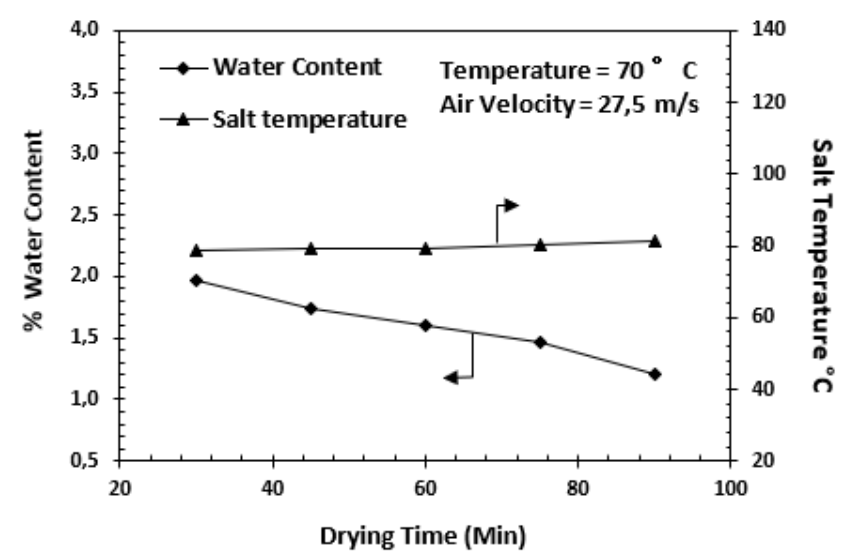

Figure 6 Drying times' effect on salt's water content and temperature

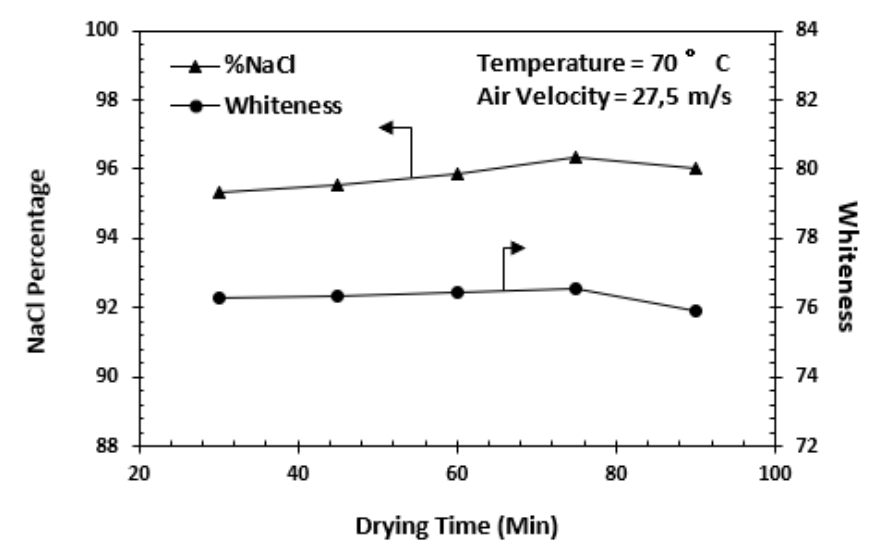

Figure 7 Drying times' effect on $\mathrm{NaCl}$ percentage and whiteness

The temperature and air velocity were kept constant at $70^{\circ} \mathrm{C}$ and $27.5 \mathrm{~m} / \mathrm{s}$, respectively. Figure 6 shows that the water content decreased as the salt particles' temperature and the drying time increased. The $30 \mathrm{~min}$. drying time adequately dried the salt particles to less than $2 \%$ water content. At drying times of $30-90 \mathrm{~min}$., the $\mathrm{NaCl}$ percentage and whiteness increased with drying times to their ultimate values and then decreased. Longer drying times were observed to raise the salt particles' temperature. At 
drying times beyond 75 min., a yellow color appeared alongside decreases in $\mathrm{NaCl}$ percentage and whiteness, as Figure 7 shows.

\subsection{Hot Air Performance}

This subsection examines the experiments' hot air performance in terms of energy consumption and drying energy efficiency, as Table 2 shows.

Table 2 Energy consumption and energy efficiency for different temperatures, air velocities, and drying times

\begin{tabular}{cccl}
\hline Variation & Variable & $\begin{array}{c}\text { Energy consumption } \\
(\mathrm{kWh})\end{array}$ & $\begin{array}{c}\text { Energy } \\
\text { efficiency }\end{array}$ \\
\hline \multirow{2}{*}{$\begin{array}{c}\text { Temperature } \\
\left({ }^{\circ} \mathrm{C}\right)\end{array}$} & 50 & 1.62 & 0.165 \\
& 70 & 1.71 & 0.168 \\
& 80 & 1.81 & 0.166 \\
& 90 & 1.90 & 0.163 \\
Air velocity (m/s) & 22.5 & 2.01 & 0.161 \\
& 24.4 & 1.76 & 0.160 \\
& 27.5 & 1.77 & 0.162 \\
& 30 & 1.79 & 0.166 \\
& 45 & 1.80 & 0.170 \\
Drying time & 60 & 1.81 & 0.170 \\
(min) & 75 & 2.71 & 0.166 \\
& 90 & 3.61 & 0.113 \\
& & 4.51 & 0.086 \\
\hline
\end{tabular}

Increasing temperatures and drying times increased energy consumption but decreased drying energy efficiency because the energy consumption was directly proportional to the electric current required to increase the heater's temperature and required drying time. However, increasing air velocities improved drying energy efficiency. Increased air velocities consumed less energy than increasing temperatures and drying times, and they more significantly reducing the water content. Increasing drying times to more than $30 \mathrm{~min}$. was unfavorable because most of the water content was determined to have been removed by $30 \mathrm{~min}$., decreasing the drying energy efficiency. Therefore, both temperature and air velocity should be correctly selected to reduce energy consumption and increase drying energy efficiency. An average $1.79 \mathrm{kWh}$ of energy was consumed to produce $5 \mathrm{~kg}$ of dried salt from crude solar sea salt at optimum operating parameters with a hot air dryer.

\subsection{Salt Quality and Specific Energy Consumption}

Salt quality assessments are essential in the production of high-quality salt suitable for industry. Water content, $\mathrm{NaCl}$ percentage, and whiteness are required for the food industry. Table 3 compares the results and experimental operating conditions of a fixed-bed hot air dryer (the current study) and a rotary hot air dryer (Han et al., 2019). 
Table 3 Operating conditions of a fixed-bed hot air dryer (the current study) versus a rotary hot air dryer (Han et al., 2019)

\begin{tabular}{lcc}
\hline \multicolumn{1}{c}{ Description } & Present study & Han et al. (2019) \\
\hline Type of hot air dryer & Fixed-bed & Rotary \\
Equipment dimension (mm) & $600 \times 400 \times 200$ & $\emptyset 200 \times 248$ \\
Rotational speed (rpm) & - & $1.0-1.5$ \\
Drying temperature $\left({ }^{\circ} \mathrm{C}\right)$ & $50,60,70,80,90$ & $50,75,100$ \\
Drying time (minute) & $30,45,60,75,90$ & $10,20,30$ \\
Initial water content (wb) & $11.5 \%$ & $13.33 \%$ \\
Final water content (wb) & $1.73 \%$ & $4.7 \%$ \\
Initial nacl (\%) & 91.3 & 96.5 \\
Final nacl (\%) & 96.91 & 98.6 \\
Initial whiteness & 72.5 & 58.5 \\
Final whiteness & 77.74 & 67 \\
Specific energy consumption $(\mathrm{kwh} / \mathrm{kg})$ & 0.35 & 0.3 \\
\hline
\end{tabular}

Both studies reported increased salt quality via increased temperatures and drying times up to a certain value. A yellow color appeared at higher temperatures, resulting in low-quality salt. The calculated average increase in $\mathrm{NaCl}$ content was $5.61 \%$ for the current study, and the removed water content was $9.77 \%$. These values were higher than the corresponding values reported by $\mathrm{Han}$ et al. (2019) of $2.1 \% \mathrm{NaCl}$ content and $8.63 \%$ removed water content. However, the previous study reported 8.5-percentage-point higher whiteness than the current study (2.1 percentage points). Thus, the present study's dryer performed better in increasing $\mathrm{NaCl}$ content and whiteness. The present study's specific energy consumption was $0.35 \mathrm{kWh} / \mathrm{kg}$ of evaporated water. The comparison with Han et al. (2019) also revealed that, for a convective-heat hot air dryer (ChHD) with a unit capacity of $2 \mathrm{~kg}$ of solar salt, the specific energy consumption was slightly lower than the current study, at $0.3 \mathrm{kWh} / \mathrm{kg}$ of evaporated water. This difference was probably due to the higher power required for the blower in the present study; however, this requirement produced more heat energy, which led to a higher drying rate. Consequently, the previously achieved ChHD drying rate $(2.1 \mathrm{~g} / \mathrm{min}$.) was lower than the corresponding rate in the current study (16.3 g/min.). Drying rates are a critical factor; dryers with high drying rates are preferable for many industries (Tatemoto et al., 2018), and the use of hot air drying has been reported in many food studies beyond salt production (Liu et al., 2020; Maftoonazad et al., 2020; Taghinezhad et al., 2020). The current study's results underline the advantages of using hot air drying to improve salt quality and reduce energy consumption.

\section{Conclusions}

This experimental investigation showed that salt's water content decreased with increasing operating parameters, such as temperature, air velocity, and drying time. Increased salt temperatures were associated with increased operating parameters. At several given operating parameters, the salt's $\mathrm{NaCl}$ percentage and whiteness initially increased to an optimum value and then decreased. Temperature, air velocity, and drying time were found to be critical parameters for hot air drying; therefore, they should be correctly selected for better salt quality. This study also found that, by correctly setting a parameter, the energy required to produce $1 \mathrm{~kg}$ of dried salt $(\mathrm{NaCl}$ of $96.91 \%$ and whiteness of 77.74) from crude solar sea salt was $0.358 \mathrm{kWh}$. This result shows that hot air dryers are economical for drying high-water-content salt to enhance its quality. 


\section{Acknowledgements}

The authors gratefully acknowledge the research funding scheme Penelitian Penugasan from the University of Trunojoyo Madura, Indonesia (Nr.: 163/UN46.4.1/PT.01.03/2020). Also, the authors thank Mr. Hamzah Muhammad Ba'abud and Mr. Muhammad Jawad for their kind support and advice.

\section{References}

Aslfattahi, N., Rahman, S., Mohd Sabri, M.F., Arifutzzaman, A., 2019. Experimental Investigation of Thermal Stability and Enthalpy of Eutectic Alkali Metal Solar Salt Dispersed with MgO Nanoparticles. International Journal of Technology, Volume 10(6), pp. 1112-1119

Das, I., Arora, A., 2018. Alternate Microwave and Convective Hot Air Application for Rapid Mushroom Drying. Journal of Food Engineering, Volume 223, pp. 208-219

Deepika, S., Sutar, P.P., 2018. Combining Osmotic-Steam Blanching with InfraredMicrowave-Hot Air Drying: Production of Dried Lemon (Citrus limon L.) Slices and Enzyme Inactivation. Drying Technology, Volume 36(14), pp. 1719-1737

Gao, Y., Wu, S., Sun, Y., Cong, R., Xiao, J., Ma, F., 2019. Effect of Freeze-Dried, Hot Air Dried and Fresh Onions on the Composition of Volatile Sulfocompounds in Onion Oils. Drying Technology, Volume 37(11), pp. 1427-1440

Han, J.W., Kim, W., Lee, H.J., 2019. Feasibility of Applying Conductive Heat and Convective Heat to the Drying Process of Safe Solar Salt. Journal of Biosystems Engineering, Volume 44, pp. 236-244

Harahap, M.M.Y., Suryantini, R., Paramita, K.D., Yatmo, Y.A., 2020. Sun-Drying in Traditional Brickmaking: Strategies for Achieving Efficiency. International Journal of Technology, Volume 11(7), pp. 1414-1421

Heydarieh, A., Arabameri, M., Ebrahimi, A., As'habi, A., Marvdashti, L.M., Yancheshmeh, B.M., Abdolshahi, A., 2020. Determination of Magnesium, Calcium and Sulphate Ion Impurities in Commercial Edible Salt. Journal of Chemical Health Risks, Volume 10(2), pp. 93-102

Jafari, H., Farahbod, F., 2017. The Experimental Survey on the Rotary Dryer Performance: Drying of Wetted Salt from Effluent Bio Wastewater. Journal of Applied Biotechnology \& Bioengineering, Volume 4(3), pp. 567-570

Juwono, F., 2020. National Salt Needs. The Indonesian Ministry of Marine Affairs and Fisheries. Available Online at https://kkp.go.id/an-component/media/uploadgambar-pendukung/DitJaskel/publikasi-materi-2/garam-nasional/02\%20\%20Fridy\%20Juwono\%20-\%20Kemenperin.pdf, Accessed on October 1, 2020

Khamtree, S., Ratanawilai, T., Nuntadusit, C., 2019. An Approach for Indirect Monitoring of Moisture Content in Rubberwood (Hevea brasiliensis) during Hot Air Drying. Drying Technology, Volume 37(16), pp. 2116-2125

Khormali, A., Petrakov, D.G. Farmanzade, A.R., 2016. Prediction and Inhibition of Inorganic Salt Formation under Static and Dynamic Conditions - Effect of Pressure, Temperature, and Mixing Ratio. International Journal of Technology, Volume 7(6), pp. 943-951

Kuganathan, N., Chroneos, A., 2018. Defects, Dopants and Sodium Mobility in $\mathrm{Na}_{2} \mathrm{MnSiO}_{4}$. Scientific Reports, Volume 8(1), pp. 5-11

Maftoonazad, N., Dehghani, M.R., Ramaswamy, H.S., 2020. Hybrid Microwave-Hot Air Tunnel Drying of Onion Slices: Drying Kinetics, Energy Efficiency, Product Rehydration, Color, and Flavor Characteristics. Drying Technology, https://doi.org/10.1080/07373937.2020.1841790 
McGee, J.T., Diosady, E.L., 2016. Investigation of Discoloration of Packaged Fortified Salt under Conditions Relevant to Product Packaging and Storage. Food and Nutrition Sciences, Volume 7(13), pp. 1221-1231

Li, H., Wen, H., Stowell, J.G., Morris, K.R., Byrn, S.R., 2010. Crystal Quality and Physical Reactivity in the Case of Flufenamic Acid (FFA). Journal of Pharmaceutical Sciences, Volume 99(9), pp. 3839-3848

Liang, Z., Tong, L., Yin, S., Liu, C., Wang, L., 2020. Bidirectional Hot Air Drying: An Effective Inhibitor of the Browning of Biomass Similar to Thick-Layered Honeysuckle. Drying Technology, https://doi.org/10.1080/07373937.2020.1771569

Liu, Z.L., Bai, J.W., Wang, S.X., Meng, J.S., Wang, H., Yu, X., Gao, Z.J., Xiao, H.W., 2020. Prediction of Energy and Exergy of Mushroom Slices Drying in Hot Air Impingement Dryer by Artificial Neural Network. Drying Technology, https://doi.org/10.1080/07373937.2019.1607873

Palamba, P., Ramadhan, M.L., Pamitran, A.S., Prayogo, G., Kosasih, E.A., Nugroho, Y.S., 2018. Drying Kinetics of Indonesian Peat. International Journal of Technology, Volume 9(5), pp. 1006-1014

Perera, D., Ganeshalingam, S., Kuganathan, N., Chroneos, A., 2019. A Computational Study of Defects, Li-Ion Migration and Dopants in Li2ZnSio4 Polymorphs. Crystals, Volume 9(11), pp. 15-21

Qadir, H., Farrukh, M.A., Aurangzaib, M., 2005. Production of Table Salt from Kohat Rock Salt. Journal of Applied Sciences, Volume 5(1), pp. 12-14

Rochwulaningsih, Y., Gozan, M., Effendy, M., Masruroh, N.N., Wardoyo, W.W., 2019a. Palung Salt in Bali: Strategies for the Local Product to Penetrate Global Markets. International Journal of Trade and Global Markets, Volume 12(2), pp. 146-167

Rochwulaningsih, Y., Sulistiyono, S.T., Utama, M.P., Efendy, M., Gozan, M., 2019b. Traditional Knowledge System in Palung Salt-Making in Bali Island. Journal of Ethnic Foods, Volume 6(10), pp. 1-7

Sofyan, N., Ridhova, A., Yuwono, A.H., Sianturi, M.C., 2019. Effect of NaCl Addition on Nano Rosette $\mathrm{TiO}_{2}$ Crystal Growth during Hydrothermal Deposition. International Journal of Technology, Volume 10(6), pp. 1235-1242

Sonnenfeld, P., 1995. The Color of Rock Salt-A Review. Sedimentary Geology, Volume 94(34), pp. 267-276

Taghinezhad, E., Kaveh, M., Khalife, E., Chen, G., 2020. Drying of Organic Blackberry in Combined Hot Air-Infrared Dryer with Ultrasound Pretreatment. Drying Technology, https://doi.org/10.1080/07373937.2020.1753066

Tatemoto, Y., Ogawa, R., Iyota, H., 2018. Measurement of Constant Drying Rate of Wet Material Placed in a Fluidised Bed of Inert Particles under Reduced Pressure. Drying Technology, Volume 36(11), pp. 1380-1386

Zhao, L., Li, J., Pan, Y., 2008. Investigation on Drying of Salt Granules and the Air Distributing System of Fluidised Bed. Drying Technology, Volume 26, pp. 1369-1372

Zhu, A., 2018. The Convective Hot Air Drying of Lactuca Sativa Slices. International Journal of Green Energy, Volume 15(3), pp. 201-207 